\title{
PARA ONDE APONTAM AS ATUAIS DIRETRIZES CURRICULARES? Um olhar sobre as DCNs de engenharia
}

\author{
Instituto Federal de Educação, Ciência e Tecnologia do Rio Grande do Norte - IFRN \\ Ana Lúcia Sarmento Henrique \\ Instituto Federal de Educação, Ciência e Tecnologia do Rio Grande do Norte - IFRN
}

Kleiton Cassemiro

\begin{abstract}
Resumo
Estabelecer uma diretriz, seja para o traçado de uma estrada ou de um currículo, traz em si uma gama de intenções que refletem o poder de quem a projeta, fazendo emergir, assim, alguns questionamentos acerca dos caminhos e intenções dessa diretriz. Entre essas questões, uma nos guiará neste artigo: todos os currículos adotados por nossas instituições de ensino preparam o indivíduo para pensar soluções que auxiliem a sociedade ou existem alguns que estão mais alinhados aos interesses do mercado? A partir dessa questão, buscamos aqui algumas respostas e reflexões ao direcionarmos um outro olhar sobre as atuais Diretrizes Curriculares Nacionais (DCNs) dos cursos de Engenharia (BRASIL, 2019b), de maneira a analisar e identificar quais foram as reais intenções que levaram a suas atualizações. Para atingir este objetivo, optamos por uma pesquisa qualitativa, inicialmente bibliográfica, debruçando-nos sobre as teorias do currículo (SILVA, 2010; KLIEBARD, 2011) e artigos que abordam essas DCNs, seguida por uma análise documental sobre dispositivos (BRASIL, 2019a; BRASIL, 2019b) que levaram à instituição dessas diretrizes. Concluímos que a forte atuação do mercado durante a construção dessas DCNs resultou em um currículo baseado por competências que flexibiliza a formação, tornando-a mais empreendedora e competitiva, e menos focada nos interesses sociais.
\end{abstract}

Palavras-Chave: Currículo de engenharia, Mercado, Sociedade, Competências, Formação empreendedora.

\begin{abstract}
Establishing a guideline, whether for the design of a road or a curriculum, brings with it a range of intentions that reflect the power of those who establish it, thus raising some questions about the paths and intentions of this guideline. Among those questions, one will guide us in this paper: do all the curricula adopted by our educational institutions prepare the individual to think of solutions that help society or are there some that are more aligned with the interests of the market? From this question, we seek some answers while directing a new look on the current National Curricular Guidelines (DCNs) of engineering courses (BRASIL, 2019b), instituted by Resolution CNE/CES n ${ }^{\circ}$ $2 / 2019$, in order to analyze and identify what were the real intentions that led to their updates. To achieve this goal, we opted for a qualitative research, initially bibliographic, focusing on curriculum theories (SILVA, 2010; KLIEBARD, 2011) and papers that address said DCNs, followed by a documentary analysis on legal devices (BRASIL, 2019a; BRASIL, 2019b) that led to the institution of such guidelines. We concluded that the strong performance of the market during the construction of the DCNs resulted in a curriculum based on competencies that makes training more flexible, making it more entrepreneurial and competitive, and less focused on social interests.
\end{abstract}

Keywords: Engineering Curriculum, Market, Society, Skills, Entrepreneurial training.

ISSN 1645-1384 (online) www.curriculosemfronteiras.org

http://dx.doi.org/10.35786/1645-1384.v20.n3.04 


\section{Introdução}

Vivemos hoje uma situação peculiar no mundo, gerada pela imensa crise sanitária que eclodiu após o surgimento de um novo coronavírus. No Brasil, esta situação é mais agudizada ainda, pois a crise instalada abriu para o mundo as portas que escondiam os grandiosos problemas sociais já existentes no país e que alguns tentavam e tentam ainda, a duras penas, esconder. Refletir sobre estes problemas mais evidentes durante a pandemia em curso, pensar em soluções para resolvê-los — ligando diferentes áreas, tais como saúde, educação, economia e também as engenharias, em suas mais diversas habilitações: sanitária, ambiental, mecânica, civil, dentre outras — passou a ser primordial neste momento. É impossível não pensar na importância e no protagonismo dos profissionais dessas áreas durante o processo de busca por soluções para resolvermos este problema que nos é colocado. Dito isto, algumas questões surgem: todos os currículos adotados por nossas instituições de ensino preparam o indivíduo para pensar soluções que auxiliem a sociedade ou existem alguns mais alinhados aos interesses do mercado? Os(as) engenheiros(as) formados(as) no Brasil desenvolvem, a partir das diretrizes curriculares de seus cursos, qual dentre esses dois tipos de perfil em sua formação?

Estabelecer uma diretriz, em termos conceituais dentro do vocabulário de Engenharia, nos remete à linha segundo a qual traçamos um determinado plano de uma estrada ou caminho. Definir o rumo que seguiremos a fim de chegarmos a um ponto preestabelecido. Seguir este trajeto com o objetivo de alcançar um ponto proposto, conceitualmente não é difícil, a questão crucial é: quem ou o que determinará o ponto de chegada? Que fatores poderão contribuir para nos orientar sobre como esta diretriz deve ser traçada, ou melhor, quem ou o que indicará para onde determinadas diretrizes devem apontar? São novas questões propostas e acreditamos que a resposta para todas está diretamente relacionada à cultura hegemônica existente no tempo social em que tais diretrizes foram geridas, sejam elas para o traçado de uma estrada ou a construção de um determinado currículo, tratado aqui como ordenador da carreira do(a) estudante. É essa cultura que geralmente se impõe para determinar quais diretrizes devemos seguir, transformando-as em seu instrumento de poder.

Não é difícil identificar, uma vez que se sabe quais poderes são predominantes em determinado tempo, para onde apontam algumas diretrizes. Basta-nos analisar atentamente os caminhos que elas percorrem, afastando as diversas "máscaras" que findam por se mostrar como verdadeiros engodos e que, muitas vezes, são introduzidas no trajeto com o intuito de apaziguar embates com grupos contra hegemônicos. No entanto, um olhar atento é capaz de identificar estas "máscaras", descortinando as reais intenções que sempre estiveram por trás da construção de qualquer diretriz.

Este é o objetivo do presente artigo: direcionar um outro olhar sobre as atuais Diretrizes Curriculares Nacionais (DCNs) dos cursos de graduação em Engenharia, apresentadas pela Resolução CNE/CES n²/2019, de maneira a analisar e identificar o que realmente provocou suas atualizações durante o primeiro ano do atual governo. Ano em que também foram atualizadas as Diretrizes Curriculares de outros cursos de graduação, quais sejam: Arquitetura e Urbanismo; Medicina Veterinária; Psicologia; e Formação Inicial de 
Professores para a Educação Básica. Para esta última, também foi instituída a Base Nacional Comum para a Formação Inicial de Professores da Educação Básica (BNC-Formação), todas precedidas por reformas controversas, tais como a Reforma Trabalhista (Lei 13.467/2017) ${ }^{1}$, a Reforma do Ensino Médio (Lei 13.415/2017) ${ }^{2}$ e a PEC 55/2016 (Emenda Constitucional no 95/2016), que estabelece um limite para os gastos primários do Governo Federal ao instituir "o Novo Regime Fiscal no âmbito dos Orçamentos Fiscal e da Seguridade Social da União, que vigorará por vinte exercícios financeiros"3.

É importante que possamos entender como se dará, a partir dessas mudanças, o percurso de formação de engenheiros(as), em um período no qual se repercutem cada vez mais casos de desastres ambientais, tais como rompimentos de barragens, desmatamentos, enchentes etc.; em um período em que a crítica à ciência se evidencia e questões políticas e ideológicas sobrepujam decisões técnicas; em um momento em que a crise sanitária, econômica e social do país é escancarada para o mundo todo a partir da pandemia de um novo vírus devastador. Neste momento, é importante saber que tipo de perfil será forjado durante a formação daqueles que serão os futuros autores e coautores do processo de preservação de nosso ambiente e, consequentemente, de nossa sociedade.

Para que possamos alcançar esse objetivo, optamos por uma pesquisa qualitativa, iniciando por uma análise bibliográfica, com o estudo de teorias sobre currículo (SILVA, 2010; KLIEBARD, 2011), de maneira a entender como se forma este "instrumento de poder" e como ele influencia no favorecimento de determinados grupos, por meio da formação do indivíduo. Em seguida, apresentamos um breve histórico sobre como se deu a criação das DCNs de Engenharia, para depois efetuarmos uma análise documental sobre as atuais diretrizes (BRASIL, 2019a; BRASIL, 2019b) e as anteriores (BRASIL, 2002a; BRASIL, 2002b), focando em uma discussão sobre os pontos acrescentados nas atuais e identificando algumas "máscaras" incluídas possivelmente para servir de engodo e esconder o real interesse da atualização dessas Diretrizes Curriculares.

\section{2. $O$ poder do currículo}

O currículo pode ser visto tanto como o conjunto das atividades já desenvolvidas por um indivíduo, quanto como o ordenador da carreira do estudante. É sobre esta segunda visão de currículo que apoiaremos esta pesquisa, tendo em vista que objetivamos adiante estudar diretrizes curriculares que atuam exatamente neste sentido.

Silva (2010), em seu estudo sobre as teorias do currículo, afirma que este é "sempre o resultado de uma seleção: de um universo mais amplo de conhecimentos e saberes selecionase aquela parte que vai constituir, precisamente, o currículo.” (SILVA, 2010, p. 15). A questão então é: quem é o responsável por esta seleção e o que é levado em consideração no momento da escolha? A resposta para esta pergunta vai depender, ressalta Silva (2010), do tipo de ser humano que se deseja entregar a determinado tipo de sociedade. Este indivíduo 
[...] será a pessoa racional e ilustrada do ideal humanista de educação? Será a pessoa otimizadora e competitiva dos atuais modelos neoliberais de educação? Será a pessoa ajustada aos ideais de cidadania do moderno estado-nação? Será a pessoa desconfiada e crítica dos arranjos sociais existentes preconizada nas teorias educacionais críticas? A cada um desses 'modelos' de ser humano corresponderá um tipo de conhecimento, um tipo de currículo (SILVA, 2010, p. 15).

O autor observa ainda que foi a partir do movimento de escolarização de massas, no início do século $\mathrm{XX}$, que o campo de estudos sobre o currículo, nos moldes como o conhecemos hoje, passou a se desenvolver, principalmente nos Estados Unidos, onde se destacam as teorias de John Franklin Bobbitt, consideradas hoje como tradicionais, para quem, segundo Silva (2010), o currículo seria uma mera questão de organização, de traçar metas para atingir determinadas habilidades, "numa perspectiva que considera que as finalidades da educação estão dadas pelas exigências profissionais da vida adulta [...]" (SILVA, 2010, p. 24).

As teorias de padronização do sistema de educação de Bobbitt, que, de acordo com Silva (2010) seguiam uma linha mais tecnocrata aos moldes do Taylorismo (fundamentada nos paradigmas da administração científica), considerando os estudantes como um produto fabril a ser processado e a educação como uma "usina de fabricação de aços" (SILVA, 2010, p.24), se difundiram rapidamente na primeira metade do século XX. Essa extrapolação da lógica empresarial para a gestão educacional implementada pelo currículo fez com que o aluno passasse a ser considerado como um "material bruto a partir do qual a escola-fábrica deveria modelar um produto de acordo com as especificações da sociedade." (KLIEBARD, 2011, p. 10). Todas essas teorias concorriam com outras mais progressistas lideradas pelo filósofo e pedagogo estadunidense John Dewey, para quem, sem deixar de ser pragmatista, o currículo deveria estar muito mais voltado para a construção da democracia do que para o fortalecimento da economia.

Ao estudarmos tais teorias do currículo, fica evidente o poder que ele tem sobre a sociedade, forjando, seja para o fortalecimento da economia ou da democracia, a identidade de cada aluno, ao the ser apresentado (o currículo) como "lugar e espaço de discernimento", conforme lembra Prado, Alencastro e Almeida (2017, p. 17499). "O currículo atual é fruto de discussões antigas e de uma evolução à custa de lutas travadas pela educação na busca da libertação intelectual e social do indivíduo em sua plenitude." (PRADO; ALENCASTRO; ALMEIDA, 2017, p. 17497). Lutas que têm, de um lado, defensores de uma educação mercadológica, que visa unicamente ao lucro financeiro e ao crescimento econômico e, de outro, aqueles que primam por uma educação integral do indivíduo, almejando sua libertação enquanto cidadão crítico e reflexivo.

Segundo KLIEBARD (2011), o modelo de currículo seguidor da "metáfora da produção", bastante desenvolvido após a primeira revolução industrial, teve seu declínio após os anos 1930, no entanto, essas mesmas tendências ressurgiram no currículo "em decorrência da segunda revolução industrial, às vezes, chamada de revolução eletrônica ou tecnológica." (KLIEBARD, 2011, p. 16). 
Após a década de 1960, novas teorias surgiram. As chamadas teorias críticas e póscríticas do currículo, que, diferentemente das tradicionais, estão mais preocupadas com as conexões entre saber, identidade e poder, sempre desconfiando do "status quo, responsabilizando-o pelas desigualdades e injustiças sociais. As teorias tradicionais, [diferentemente], eram teorias de aceitação, ajuste e adaptação.” (SILVA, 2010, p. 30).

Para Kliebard (2011), estas teorias tradicionais buscavam dar formações específicas para o indivíduo, a fim de fazê-lo ocupar "papéis adultos sancionados pela comunidade" (p.16). Segundo esse autor, propostas curriculares como estas seguem ainda hoje sendo divulgadas "sob a bandeira da flexibilidade curricular e do ensino individualizado." (KLIEBARD, 2011, p. 14). Isso nos mostra que ambas as teorias do currículo e suas concepções particulares, tradicionais e críticas, seguem coexistindo e influenciando de diferentes formas os currículos adotados nas instituições de ensino.

Se bem analisarmos as atuais Diretrizes Curriculares Nacionais para os cursos de Engenharia, foco deste trabalho e mais detalhadas nos tópicos seguintes, veremos que elas agem retrogradamente ao se aproximar bastante dessas teorias tradicionais, ajustando os currículos a um modelo que prima pela formação tecnicista que "tem como foco a preparação do aluno para a simples movimentação da economia [...]” (PRADO; ALENCASTRO; ALMEIDA, 2017, p. 17500), travando a possibilidade desse aluno evoluir democraticamente como cidadão e fazendo-o aceitar, sem maiores questionamentos, a sociedade como ela é. Isso demonstra o poder que está intrínseco em todas essas teorias, conforme pontua Silva (2010), ao afirmar que

[...] as teorias do currículo, na medida em que buscam dizer o que o currículo deve ser, não podem deixar de estar envolvidas em questões de poder. Selecionar é uma operação de poder. Privilegiar um tipo de conhecimento é uma operação de poder. Destacar, entre as múltiplas possibilidades, uma identidade ou subjetividade como sendo a ideal é uma operação de poder. (SILVA, 2010, p. 16).

Desta forma, as classes dominantes, capitaneadas pelo mercado e alinhando os currículos aos seus interesses, exercem o seu poder, mantendo, assim, a grande massa da população (classe trabalhadora) presa dentro de um enorme ciclo consumista e de acumulação supérflua, que a torna, portanto, incapaz de enxergar quais foram as forças que a colocaram presa nesse ciclo e quais os reais interesses dessas forças. Essa massa da população está condicionada, graças ao currículo que a formou, a pensar e a visualizar tudo em benefício próprio, de forma individualista, em um ambiente de pura competição, pouco importando o que está em sua volta. É desta maneira que a classe dominante, por meio da educação, dissemina a cultura hegemônica estabelecida e consegue ampliar sua produção e gerar mais riqueza para si. Prado, Alencastro e Almeida (2017) nos lembram bem disso, ao afirmarem que

[...] os governantes utilizam o currículo para moldar a cultura da sociedade à sua maneira, impondo valores que vão ao encontro de interesses próprios das classes dominantes, com objetivos focados no trabalho para alavancar a produção e gerar 
mais riqueza para sua classe. (PRADO; ALENCASTRO; ALMEIDA, 2017, p. 17500).

É através de determinados tipos de mecanismos que esses governos garantem a não contestação do estado atual da sociedade, afirma Silva (2010) ao analisar o famoso ensaio do filósofo francês Louis Althusser: "A ideologia e os aparelhos ideológicos de estado". Tais mecanismos fazem uso de aparelhos repressivos de estado como a polícia e o judiciário, e de aparelhos ideológicos (religião, mídia, família e escola). Dentre estes, a escola, segundo análise de Silva (2010), funciona como aparelho central do estado, pois é capaz de atingir toda a população, por um período prolongado de tempo. É por este motivo que o controle desse aparelho é tão disputado pelos grupos dominantes, que evidentemente reconhecem o seu poder ideológico e, por isso, lutam para mantê-lo, distanciando ao máximo a educação de uma formação mais geral e emancipatória, pois sabem que

[...] a ideologia atua de forma discriminatória: ela inclina as pessoas das classes subordinadas à submissão e à obediência, enquanto as pessoas das classes dominantes aprendem a comandar e a controlar [desta forma] a escola contribui para a reprodução da sociedade capitalista ao transmitir, através das matérias escolares, as crenças que nos fazem ver os arranjos sociais existentes como bons e desejáveis. (SILVA, 2010, p. 32).

Não é à toa que a matéria Empreendedorismo ganhou tanto espaço nos currículos escolares do ensino básico, assim como nas diretrizes curriculares de cursos de nível superior, como é o caso dos cursos de Engenharia, na tentativa de fazer com que toda a sociedade considere esta alternativa de trabalho "boa e desejável", além de acessível a todos, como abordaremos melhor no tópico 3 deste artigo. É interessante lembrar também que, no lastro desses ideais das classes dominantes, projetos como o "Programa Escola Sem Partido" (PL $\left.n^{\circ} 246 / 2019\right)^{4}$ ganharam força nos últimos anos e têm se tornado carro-chefe de campanhas governamentais em todas as esferas de governo.

Nessa perspectiva de currículo funcional ao mercado, também se insere a educação profissional com uma abordagem instrumental, a fim de ajudar a manter o status quo, cuja centralidade, no sistema capitalista neoliberal, é a economia. É importante termos consciência de que os movimentos contra hegemônicos não pretendem dissociar a educação profissional da educação geral de cunho crítico-reflexivo, ou seja, da educação humana. O que se pretende é "deslocar a centralidade da dimensão econômica para a dimensão humana" sem necessariamente desconsiderar a dimensão econômica, afirma Moura (2020), em uma palestra on-line sobre a Reforma do Ensino Médio (Lei no 13.415/2017). Para Moura (2020), este "deslocamento da centralidade" significa refletir sobre a seguinte questão:

É necessário [...] que a economia e o que se produz por meio [dela] esteja centralizado cada vez mais nas mãos das grandes empresas transnacionais e, por consequência, em alguns poucos seres humanos, ou é possível que o que é produzido pela própria classe trabalhadora, ao se inserir na economia, o resultado 
[disto] possa ser socializado com a própria classe trabalhadora? (MOURA, 2020, aos 26min26s).

Nosella (2019) destaca que a luta travada por vozes progressistas como as de John Dewey, Anísio Teixeira, os pioneiros da educação e muitos outros até os dias de hoje, não é por um currículo que promova a dissociação entre a educação profissional e a geral, mas sim o contrário. Essas vozes são "defensoras, em geral, da necessidade de instruir as massas populares integrando cultura geral e profissional." (NOSELLA, 2019, p. 15, grifo nosso). A própria Lei de Diretrizes e Bases da Educação Nacional (LDB nº 9.394/1996) estabelece em seu artigo primeiro, parágrafo $2^{\circ}$ que "a educação escolar deverá vincular-se ao mundo do trabalho e à prática social.” (BRASIL, 1996, n.p.). O Plano Nacional de Educação (PNE, Lei no 13.005/2014) reforça essa ideia ao inserir em suas diretrizes a "formação para o trabalho e para a cidadania, com ênfase nos valores morais e éticos em que se fundamenta a sociedade" e também a "promoção humanística, científica, cultural e tecnológica do País." (BRASIL, 2014, n.p.).

O currículo, como vimos até aqui, é, portanto, uma seleção. Esta seleção não é, de maneira alguma, neutra. Ela se fundamenta em uma determinada concepção de sociedade, de homem, de educação e também na relação existente entre trabalho e educação. Nas Instituições de Ensino Superior isso não é diferente. Mesmo com toda a autonomia que elas têm, seus currículos estão parametrizados pelas Diretrizes Curriculares Nacionais de cada curso, conforme atribuições fixadas pela LDB $\mathrm{n}^{\mathbf{0}}$ 9.394/1996, ao determinar que as Universidades devem "fixar os currículos dos seus cursos e programas, observadas as diretrizes gerais pertinentes [...]” (BRASIL, 1996, n.p., grifo nosso).

É desta forma que entramos na análise das atuais DCNs dos cursos de Engenharia, traçando seu histórico de concepção, seus objetivos, perfil e competências que elas propõem para os alunos.

\section{As DCNs de engenharia - objetivos, perfis e competências}

Lançando mão novamente da metáfora relativa à diretriz de uma estrada, iniciaremos agora o estudo das atuais diretrizes traçadas para os cursos de Engenharia, inicialmente percorrendo os caminhos que levaram à sua elaboração — através da análise do histórico das DCNs de Engenharia no Brasil e dos documentos que antecederam as atuais - em seguida analisaremos os objetivos, perfil e competências propostos para os(as) engenheiros(as), a partir do discurso presente na Resolução CNE/CES n ${ }^{\circ} 1 / 2019$, que institui as novas Diretrizes Curriculares para os cursos de Engenharia no Brasil.

\subsection{Uma breve história sobre as DCNs de Engenharia no Brasil}

O processo de implantação das Diretrizes Curriculares para os cursos de Engenharia, teve início a partir da edição das Leis no 9.131/1995 e 9.394/1996. A primeira, responsável 
pela criação do Conselho Nacional de Educação (CNE) e a segunda, pelo estabelecimento das Diretrizes e Bases da Educação Nacional (LDB). Em dezembro de 1997, o CNE, recémcriado conforme lei mencionada anteriormente, emite um parecer que trata das diretrizes curriculares para os cursos superiores, o Parecer $n^{\circ} 776 / 1997^{6}$. Em seguida, no mesmo mês, o MEC publica o Edital n ${ }^{\circ}$ 04, de 10 de dezembro de $1997^{7}$, que convoca as instituições de educação superior (IES) a apresentar propostas de elaboração para as novas diretrizes curriculares.

Antes destas medidas supracitadas, os cursos de graduação em Engenharia seguiam o currículo mínimo instituído 20 anos antes pela Resolução do extinto Conselho Federal de Educação, CFE no 48/1976, conforme afirma Oliveira (2019b).

Em 2002, são então instituídas as primeiras Diretrizes Curriculares Nacionais (DCNs) dos cursos de graduação em Engenharia, estabelecidas pela Resolução CNE/CES n ${ }^{\circ} 11$, de 11 de março de 2002 (Brasil, 2002b) e fundamentadas no Parecer CNE/CES n 1.362/2001, aprovado em 12 de dezembro de 2001 (Brasil, 2002a), que, dentre outras coisas, afirma

Nesta proposta de Diretrizes Curriculares, o antigo conceito de currículo, entendido como grade curricular que formaliza a estrutura de um curso de graduação, é substituído por um conceito bem mais amplo, que pode ser traduzido pelo conjunto de experiências de aprendizado que o estudante incorpora durante o processo participativo de desenvolver um programa de estudos coerentemente integrado. (BRASIL, 2002a, n.p.).

Segundo Oliveira (2019b), "enquanto a Resolução no 48/1976 tinha como cerne a grade curricular com matérias predefinidas, a Resolução $n^{\circ}$ 11/2002 previa a existência de um projeto pedagógico, decretando o fim do currículo mínimo para o curso de Engenharia." (OLIVEIRA, 2019b, p. 27).

Desta forma, as DCNs de 2002 passaram a ser a base para a elaboração dos projetos pedagógicos dos cursos de Engenharia, permanecendo vigentes até surgirem novas demandas por mudanças no seu conteúdo, que desta vez tiveram a forte participação de um setor relacionado com o mercado de trabalho: a Mobilização Empresarial pela Inovação (MEI/CNI). Essas demandas, na verdade, já vinham sendo discutidas desde meados de 2009, principalmente em eventos promovidos pela Associação Brasileira de Educação em Engenharia (ABENGE). Antes disso, outras diretrizes foram criadas para cursos específicos de Engenharia: Engenharia agronômica (Resolução CNE/CES 01/2006) ${ }^{8}$; Engenharia agrícola $(2 / 2006)^{9}$; Engenharia de pesca $(5 / 2006)^{10}$ e Engenharia geológica $(1 / 2015)^{11}$.

Finalmente, em 8 de julho de 2015, foi indicada a constituição de uma comissão da Câmara de Educação Superior (CES) para revisão das Diretrizes Curriculares dos Cursos de Engenharia, instituída pela Portaria CNE/CES nº 6, de 12 de novembro de 2015, conforme descrito no Parecer CNE/CES nº 01/2019 (BRASIL, 2019a).

Todas essas discussões prosseguiram nos anos posteriores por meio de reuniões das comissões, promovidas pelo relator da revisão das DCNs, professor Antonio de Araújo Freitas Júnior (engenheiro civil e presidente do CNE, com doutorado em Engenharia de 
produção), audiências públicas e eventos promovidos pela ABENGE, como o Congresso Brasileiro de Educação em Engenharia (COBENGE), até o fim de 2018, quando foram unificadas todas as propostas existentes sobre as novas DCNs.

A participação e o protagonismo da MEI/CNI em todo esse processo, conforme mencionado anteriormente, já denunciava quais caminhos as novas DCNs tomariam com o intuito de moldar os novos perfis dos(as) engenheiros(as) formados(as) a partir de sua instituição, estabelecida pela Resolução CNE/CES n 1/2019 (Brasil, 2019b) e baseada no Parecer CNE/CES nº 1/2019 Brasil, 2019a). Dada a relevância dessa participação para a análise proposta neste artigo, deixaremos seu detalhamento para um tópico específico.

É importante lembrar aqui que essas discussões sobre as mudanças nas DCNs dos cursos de Engenharia ocorreram dentro de um cenário nacional que já vinha passando por mudanças no mundo do trabalho, com destaque para a Reforma Trabalhista de 2017, instrumentalizada pela Lei $n^{\circ} 13.467 / 2017$, que instituiu uma mudança significativa na Consolidação das Leis do Trabalho, com a promessa de combater o desemprego e a crise econômica no país. Sobre este tema deixaremos também para tratar mais adiante, quando abordaremos a questão do empreendedorismo e sua inserção nas atuais DCNs, matéria tão difundida pelos órgãos que controlam o mercado e aos poucos diluída nos currículos educacionais impostos pelo atual governo, inclusive no ensino médio.

Passemos agora para a análise dos objetivos das novas DCNs comparando-os com os das anteriores, a fim de buscar uma resposta para a questão colocada no título do presente artigo: Para onde apontam as atuais Diretrizes Curriculares dos Cursos de Engenharia?

\subsection{Acerca dos objetivos das Diretrizes Nacionais Curriculares para Cursos de Engenharia}

Em 2019, tão logo foi aprovada a atualização das DCNs dos Cursos de Engenharia, foi lançado um livro intitulado: A Engenharia e as novas DCNs - Oportunidades para formar mais e melhores engenheiros. Organizado pelo engenheiro Vanderli Fava de Oliveira (presidente da Associação Brasileira de Educação em Engenharia), este livro corresponde a uma coletânea de artigos elaborados por diversos pesquisadores e publicados com o intuito de melhor orientar as IES durante o processo de atualização de seus PPCs (Projetos Pedagógicos de Curso) para atender às novas diretrizes. Dentre os artigos constantes do livro, encontramos um escrito pelo próprio Oliveira com o seguinte título: "As inovações nas atuais diretrizes para a Engenharia: estudo comparativo com as anteriores" (OLIVEIRA, 2019a), que basicamente busca demonstrar o quão inovadoras foram as novas DCNs para os cursos de Engenharia, quando comparadas às diretrizes anteriores. Nós nos baseamos nesse artigo para empreender nossa investigação, não replicando a mesma comparação estabelecida pelo autor, mas buscando analisar as diferentes nuances textuais existentes no discurso de cada Resolução (2002 e 2019), a fim de encontrar uma resposta para a questão que propusemos inicialmente.

Vejamos, pois, quais são os objetivos descritos nas duas resoluções em seus artigos 1 e 2. Na Resolução CNE/CES n 11/2002 (Brasil, 2002b) temos a seguinte informação: 
Art. $1^{\circ}$ A presente Resolução institui as Diretrizes Curriculares Nacionais do Curso de Graduação em Engenharia, a serem observadas na organização curricular das Instituições do Sistema de Educação Superior do País.

Art. $2^{\circ}$ As Diretrizes Curriculares Nacionais para o Ensino de graduação em Engenharia definem os princípios, fundamentos, condições e procedimentos da formação de engenheiros, estabelecidas pela Câmara de Educação Superior do Conselho Nacional de Educação, para aplicação em âmbito nacional na organização, desenvolvimento e avaliação dos projetos pedagógicos dos cursos de graduação em Engenharia das Instituições do Sistema de Ensino Superior (BRASIL, 2002b, p. 01, grifo nosso).

Pode-se observar que o primeiro artigo das Diretrizes apresenta, na verdade, a finalidade da Resolução que é unicamente instituir as DCNs de Engenharia em 2002. Somente no artigo $2^{\circ}$ desse documento é que viria a ser detalhada a função das Diretrizes — " [...] definem os princípios, fundamentos, condições e procedimentos da formação de engenheiros[...]" - e para que (qual objetivo) elas se destinam — " [...] para aplicação em âmbito nacional na organização, desenvolvimento e avaliação dos projetos pedagógicos dos cursos de graduação em Engenharia das Instituições do Sistema de Ensino Superior.” (BRASIL, 2002b, grifo nosso).

Fica evidente, então, a existência de dois objetivos distintos no documento em análise: um para a Resolução no artigo $1^{\circ}$ (instituição das Diretrizes) e outro para as Diretrizes no artigo $2^{\circ}$ (definição de princípios e identificação do objetivo das Diretrizes).

Observemos a seguir a transcrição dos artigos 1 e 2 da Resolução CNE/CES n²/2019 (BRASIL, 2019b) que instituiu as atuais DCNs dos cursos de Engenharia.

Art. $1^{\circ}$ A presente Resolução institui as Diretrizes Curriculares Nacionais do Curso de Graduação em Engenharia (DCNs de Engenharia), que devem ser observadas pelas Instituições de Educação Superior (IES) na organização, no desenvolvimento e na avaliação do curso de Engenharia no âmbito dos Sistemas de Educação Superior do País.

Art. $2^{\circ}$ As DCNs de Engenharia definem os princípios, os fundamentos, as condições e as finalidades, estabelecidas pela Câmara de Educação Superior do Conselho Nacional de Educação (CES/CNE), para aplicação, em âmbito nacional, na organização, no desenvolvimento e na avaliação do curso de graduação em Engenharia das Instituições de Educação Superior (IES). (BRASIL, 2019b, p. 01, grifo nosso).

Na interpretação de Oliveira (2019a), os objetivos das atuais Diretrizes se misturam com os de sua Resolução, levando-o a crer que

A atual resolução [2019] acrescenta como objetivo [em seu artigo $1^{\circ}$ ], além da organização, o desenvolvimento e a avaliação do curso de Engenharia. Este acréscimo é benéfico, pois indica a necessidade de os cursos abordarem tais 
questões em seus projetos pedagógicos, assim como sinaliza a importância de ajustes nos instrumentos oficiais de avaliação [...] (OLIVEIRA, 2019a, p. 67).

No entanto, a partir da leitura destes dois artigos, é possível identificar que não houve acréscimo significativo nos objetivos das Diretrizes, conforme indicado por Oliveira (2019a) em referência ao novo texto do artigo primeiro da Resolução de 2019 (BRASIL, 2019b). Percebe-se, na verdade, praticamente uma replicação nesse artigo, ao repetir o que já estava inserido no segundo (ver destaque na transcrição dos artigos acima). Sendo assim, as duas Resoluções (2002 e 2019) mantiveram basicamente os mesmos objetivos para as DCNs, com uma pequena, mas não menos importante, modificação no texto: as atuais DCNs excluíram a expressão "projetos pedagógicos" dos objetivos apresentados nos artigos 1 e 2, ou seja, onde lia-se: “[...] na organização, desenvolvimento e avaliação dos projetos pedagógicos dos cursos de graduação em Engenharia [...]” (Brasil, 2002b, grifo nosso), lê-se agora: “[...] na organização, no desenvolvimento e na avaliação do curso de Engenharia [...]" (BRASIL, 2019b, p. 01 grifo nosso).

Esta omissão é, no mínimo, curiosa, considerando que o próprio Parecer CNE/CES n ${ }^{\circ}$ 1/2019 (BRASIL, 2019a), que serviu de base para a Resolução CNE/CES no 2/2019, determina que "o Projeto Pedagógico do Curso de Graduação em Engenharia (PPC) ocupa posição proeminente na proposta das novas Diretrizes Curriculares Nacionais do Curso de Graduação em Engenharia.” (BRASIL, 2019a, p. 27), e segue afirmando ainda que o PPC evidencia "a coerência existente entre os objetivos do curso, o perfil do egresso e a matriz curricular, tomando por referência as DCNs e as recomendações do Enade [...]" (BRASIL, 2019a, p. 27, grifo nosso). Uma mudança desnecessária e tendenciosa, pois minimiza, ao nosso ver, o papel do PPC do curso, transformando as DCNs em um instrumento mais de imposição do que de referência, contrariando o que diz o próprio parecer que as fundamenta.

Outra pequena mudança que pode ilustrar essa tendência impositiva das DCNs está na inserção do verbo dever no artigo $1^{\circ}$. Onde lia-se em 2002: “A presente Resolução institui as Diretrizes Curriculares Nacionais do Curso de Graduação em Engenharia, a serem observadas na organização curricular das Instituições [...]” (BRASIL, 2002b, p. 01, grifo nosso), foi substituído por: "A presente Resolução institui as Diretrizes Curriculares Nacionais do Curso de Graduação em Engenharia, que devem ser observadas pelas Instituições [...]" (BRASIL, 2019b, p. 01, grifo nosso). Considerando que o texto anterior ao atual já apresentava clareza quanto às intenções de se instituírem as DCNs, a simples colocação deste verbo não seria de todo necessária, a não ser que houvesse uma real intenção de imposição, reforçando o que já havíamos comentado.

A exclusão da expressão "organização curricular", presente no art. $1^{\circ}$ das diretrizes anteriores, também é perceptível aqui. As atuais diretrizes afirmam apenas que elas devem ser observadas na organização do curso de Engenharia (sem a palavra curricular). Isso já denuncia o que abordaremos mais adiante em relação à flexibilização trazida pelas atuais DCNs com a adoção de um currículo por competências.

Em relação ao artigo $2^{\circ}$ das duas resoluções, apesar de Oliveira (2019a) afirmar que o de 2019 “[...] é praticamente igual ao prescrito na resolução anterior, inclusive em termos 
redacionais." (OLIVEIRA, 2019a, p. 67), podem ser observadas, assim mesmo, algumas mudanças consideráveis. A atual resolução retira das DCNs o objetivo de definir os "procedimentos da formação de engenheiros" a serem aplicados na "organização, desenvolvimento e avaliação" dos PPCs de Engenharia, conforme lia-se na resolução de 2002, priorizando apenas a definição das "finalidades" estabelecidas pela CNE/CES para aplicação "na organização, no desenvolvimento e na avaliação do curso ${ }^{12}$ de graduação em Engenharia [...]" (BRASIL, 2019b, p. 1). Os fins acabam por se sobrepor aos meios, aos métodos, aos processos de formação do(a) engenheiro(a). Fins estes que ficam mais claros nos perfis e competências que as atuais DCNs pretendem em relação aos egressos de Engenharia, e que trataremos no tópico seguinte.

\subsection{Perfil, competências e o empreendedorismo no curso de Engenharia}

Antes de analisar o perfil e as competências esperadas para os profissionais a partir do que é proposto nas atuais diretrizes para os cursos de Engenharia, precisamos fazer uma análise no contexto histórico de reformas em meio ao qual essas diretrizes foram inseridas.

Ao longo do período de discussão das DCNs de Engenharia, vislumbramos uma sequência de reformas que, de certa forma, estão interligadas com o tipo de perfil desejado para os egressos dos cursos de Engenharia nas atuais diretrizes. Dentre as reformas a se destacar nesse intervalo de tempo está, inicialmente, a PEC 55/2016 (Emenda Constitucional n 95/2016), que estabelece um limite para os gastos primários do Governo Federal ao instituir "o Novo Regime Fiscal no âmbito dos Orçamentos Fiscal e da Seguridade Social da União, que vigorará por vinte exercícios financeiros [...]” (BRASIL, 2016, n.p.), trazendo, assim, um grande impacto na educação ao interferir diretamente no seu orçamento anual. Não só na educação básica, mas também na educação superior. Eis aí, talvez, o motivo de se querer flexibilizar os currículos nas instituições de ensino — para melhor se adequar ao teto de gastos estabelecido pela PEC 55/2016.

No bojo dessas mudanças instauradas com a PEC 55/2016, mais um ataque à educação é promovido, desta vez com a Lei n ${ }^{\circ} 13.415 / 2017$, conhecida por Reforma do Ensino Médio (BRASIL, 2017a). Mais uma que também tem seu destaque no mesmo contexto, propondose a antecipar especializações para a formação básica, impedindo, assim, que o jovem tenha uma formação ampla e integral que o faça refletir sobre sua relação dentro de uma coletividade. Tudo isso graças à flexibilização de disciplinas que agora são divididas em obrigatórias e optativas, de acordo com a especialidade que cada aluno pretende seguir.

Essa flexibilização é algo que também está presente na Reforma Trabalhista instituída pela Lei $n^{\circ}$ 13.467/2017 (BRASIL, 2017b) e evidenciada nas relações entre empregado e empregador, dando ao segundo maiores vantagens em termos contratuais e ao primeiro menores garantias, além de estimular o empreendedorismo (autonomia e competitividade) com a promessa de minimizar as taxas de desemprego. $O$ resultado disto podemos ver através do grande aumento da taxa de trabalho informal, o que contribuiu significativamente para ampliar a atual crise sanitária e social em que nos encontramos. 
Todo esse contexto de reformas neoliberais que se desenhou após 2016 tem contribuído para promover, além de uma maior precarização do trabalho, a subsunção da educação às necessidades do mercado, gerando seres humanos mais competitivos e individualistas, em busca de grandes lucros por meio do empreendedorismo. Desta forma, inevitavelmente, esses valores findaram por se estender também para os perfis das atuais Diretrizes Curriculares dos cursos de Engenharia.

Sobre o perfil do egresso de Engenharia, a primeira característica apontada no inciso I do artigo $3^{\circ}$ da Resolução CNE/CES n²/2019, é a "visão holística" (BRASIL, 2019b, p. 1), que, de acordo com o Instituto Brasileiro de Coaching (IBC), significa considerar que "as propriedades do sistema não podem ser explicadas apenas pela soma dos seus componentes, pois é o todo que determina como as partes se comportam"13. Termo muito usado na administração empresarial e que vem substituir a expressão "formação generalista" presente no artigo $3^{\circ}$ da Resolução CNE/CES no 11/2002 (BRASIL, 2002b, p. 1), que, conforme o dicionário online de português, corresponde a uma "pessoa não especializada cujo conhecimento, aptidão, talento ou interesse é geral, estendendo-se a vários âmbitos ou campos"14. Observa-se que, de acordo com as atuais diretrizes, o egresso poderá ter uma "visão" do todo, o que não significa dizer que esta visão não partirá de uma especialização específica. Em 2002 esse conceito tinha um foco maior na "formação" do indivíduo e não somente sobre a visão que ele deveria ter a partir de determinada especialização. Desta forma, nas diretrizes anteriores, o egresso poderia sair de seu curso com uma formação mais geral, o que lhe daria potencialmente uma visão mais ampliada de seu trabalho e de sua função na sociedade.

A Resolução de 2002 seguia, em seu artigo $3^{\circ}$, o discurso sobre o perfil do egresso, integrando as demais características de sua formação de maneira fluida, criando uma verdadeira teia que as interliga de tal modo que, ao final, tinha-se um perfil único e coeso, com um objetivo específico: estimular uma "atuação crítica e criativa na identificação e resolução de problemas, considerando seus aspectos políticos, econômicos, sociais, ambientais e culturais, com visão ética e humanística, em atendimento às demandas da sociedade." (BRASIL, 2002b, p. 1, grifo nosso). Podemos observar, desta forma, que atender às "demandas da sociedade" era, nas diretrizes anteriores (Resolução CNE/CES n¹1/2002) a meta final da formação do(a) engenheiro(a), ou seja, para onde pareciam apontar aquelas diretrizes.

Retornando agora para as atuais diretrizes (Resolução CNE/CES n 2/2019), vejamos como são colocados os perfis que ela apresenta em seu artigo $3^{\circ}$ :

Art. $3^{\circ} \mathrm{O}$ perfil do egresso do curso de graduação em Engenharia deve compreender, entre outras, as seguintes características:

I - ter visão holística e humanista, ser crítico, reflexivo, criativo, cooperativo e ético e com forte formação técnica;

II - estar apto a pesquisar, desenvolver, adaptar e utilizar novas tecnologias, com atuação inovadora e empreendedora; 
III - ser capaz de reconhecer as necessidades dos usuários, formular, analisar e resolver, de forma criativa, os problemas de Engenharia;

IV - adotar perspectivas multidisciplinares e transdisciplinares em sua prática; $\mathrm{V}$ - considerar os aspectos globais, políticos, econômicos, sociais, ambientais, culturais e de segurança e saúde no trabalho;

VI - atuar com isenção e comprometimento com a responsabilidade social e com o desenvolvimento sustentável (BRASIL, 2019b, p. 1-2, grifo nosso).

A partir deste recorte, podemos visualizar uma adaptação no discurso das diretrizes para uma forma de apresentação em tópicos, listados sem qualquer conexão de um com o outro, além de acrescentar algumas expressões que não estavam nas diretrizes anteriores, tais como: "forte formação técnica" e "atuação inovadora e empreendedora", denotando uma maior aproximação aos interesses do mercado. Além destas, uma mudança que chama também atenção está no inciso III, em que se observa uma preocupação em analisar e resolver apenas "os problemas de engenharia". Qual a questão aqui? A questão é que a engenharia deveria estar voltada para resolver os problemas da sociedade, atender às "demandas da sociedade". Ser formado para resolver apenas problemas de engenharia é exatamente desconsiderar o todo, ou seja, desconsiderar para que serve, ou deveria servir, toda a formação do(a) engenheiro(a).

Um outro ponto que merece atenção está no inciso $\mathrm{V}$ do mesmo artigo. Nele são apresentados alguns aspectos a serem considerados no perfil do(a) engenheiro(a), dispostos de maneira extremamente vaga, que termina possibilitando qualquer postura profissional, pois, enquanto um pode considerar estes aspectos a partir de uma concepção humanística, outro pode considerá-los partindo de uma concepção econômica, instrumentalista e pragmática.

O artigo seguinte da Resolução CNE/CES n 2/2019 (artigo $4^{\circ}$ ) concentra uma das maiores diferenças entre as diretrizes anteriores, que apresentavam (em artigo de mesmo número) apenas uma lista com 13 competências a serem consideradas no momento de escolha dos conhecimentos necessários para formação do(a) engenheiro(a). Para Oliveira (2019a, p. 71) o texto apresentado no artigo $4^{\circ}$ das diretrizes anteriores levava a entender que a formação se daria a partir de conteúdos e afirma que essa "pode não ter sido a intenção dos que contribuíram para esta formulação, mas a realidade dos cursos mostra que a maioria trabalha predominantemente no oferecimento de conteúdo.” (Oliveira, 2019a, p. 71). É provável que tenha sido exatamente essa mudança conceitual sobre o currículo - de conteúdos para competências - que estimulou uma maior alteração neste ponto das atuais DCNs, levandoas a um maior detalhamento de cada competência almejada para os egressos dos cursos de Engenharia. Segundo Oliveira (2019a)

[...] fica claro que o objetivo [das atuais diretrizes] é desenvolver competências e não apenas fornecer elementos para posterior desenvolvimento. Isso determina uma mudança de concepção crucial no processo de formação do engenheiro, indicando que os projetos dos cursos devem ser formulados, não mais em função 
de conteúdos, mas com foco no desenvolvimento de competências [...] (OLIVEIRA, 2019a, p. 71).

Esse foco no desenvolvimento de competências, no entanto, traz uma certa flexibilidade para as IES na formulação dos conteúdos de seus cursos de Engenharia, ao mesmo tempo que leva também para uma ausência de uniformidade na formação exercida no mesmo curso em diferentes IES. Isso pode ser melhor observado no artigo $9^{\circ}$ da Resolução CNE/CES n ${ }^{\circ}$ 2/2019, que trata dos conteúdos. Nesse trecho das atuais resoluções, são mencionados os tipos de conteúdo que devem estar contidos no PPC (básicos, profissionais e específicos) e informados também quais conteúdos básicos devem ser contemplados, sem especificar um percentual de carga horária para nenhum tipo de conteúdo, como havia nas diretrizes anteriores (cerca de $30 \%$ de carga horária mínima para os básicos e $15 \%$ para os profissionalizantes).

Alguns conteúdos básicos ficaram ausentes nas atuais diretrizes, como é o caso de "Comunicação e Expressão" e "Humanidades, Ciências Sociais e Cidadania", que eram contemplados nas diretrizes anteriores. Este fato traz uma certa incoerência com o que está descrito no caput do artigo $9^{\circ}$ das atuais diretrizes, em que se lê:

Art. $9^{\circ}$ Todo curso de graduação em Engenharia deve conter, em seu Projeto Pedagógico de Curso, os conteúdos básicos, profissionais e específicos, que estejam diretamente relacionados com as competências que se propõe a desenvolver. A forma de se trabalhar esses conteúdos deve ser proposta e justificada no próprio Projeto Pedagógico do Curso. (BRASIL, 2019b, p. 5, grifo nosso).

Ora! Se o texto das atuais diretrizes, no artigo que trata das competências (quarto), afirma que os egressos de Engenharia devem ser capazes de "[...] realizar a avaliação críticoreflexiva dos impactos das soluções de engenharia nos contextos social, legal, econômico e ambiental [e também] comunicar-se eficazmente nas formas escrita, oral e gráfica [...]" (BRASIL, 2019b, p. 2), é de se estranhar que exatamente os conteúdos citados acima, diretamente ligados a essas competências, tenham sido subtraídos nas atuais diretrizes.

Ainda no que diz respeito à flexibilidade do currículo, ao mesmo tempo que vemos essa proposição para os conteúdos, percebemos certa inflexibilidade no momento em que as atuais DCNs definem, em seu artigo $6^{\circ}$, como devem ser os PPCs, direcionando de forma categórica o que nas diretrizes anteriores era deixado mais a critério de cada IES (certa flexibilização). Destacamos aqui um dos pontos, nesse artigo $6^{\circ}$ das atuais diretrizes, que retoma a incoerência mencionada acima, no que diz respeito à garantia de aquisição das competências exigidas na Resolução CNE/CES n 2/2019, ao afirmar que

Art. $6^{\circ} \mathrm{O}$ curso de graduação em Engenharia deve possuir Projeto Pedagógico do Curso (PPC) que contemple o conjunto das atividades de aprendizagem e assegure o desenvolvimento das competências, estabelecidas no perfil do 
egresso. Os projetos pedagógicos dos cursos de graduação em Engenharia devem especificar e descrever claramente:

$[\ldots]$

III - as principais atividades de ensino-aprendizagem e os respectivos conteúdos, sejam elas de natureza básica, específica, de pesquisa e de extensão, incluindo aquelas de natureza prática, entre outras, necessárias ao desenvolvimento de cada uma das competências estabelecidas para o egresso [...] (BRASIL, 2019b, p. 3, grifo nosso).

Para finalizar este tópico, chamamos a atenção para mais um direcionamento dado pelas atuais diretrizes, desta vez referente ao campo de atuação do(a) engenheiro(a), tratado no artigo $5^{\circ}$ da resolução, que traz o seguinte texto:

Art. $5^{\circ} \mathrm{O}$ desenvolvimento do perfil e das competências, estabelecidas para o egresso do curso de graduação em Engenharia, visam à atuação em campos da área e correlatos, em conformidade com o estabelecido no Projeto Pedagógico do Curso (PPC), podendo compreender uma ou mais das seguintes áreas de atuação: I - atuação em todo o ciclo de vida e contexto do projeto de produtos (bens e serviços) e de seus componentes, sistemas e processos produtivos, inclusive inovando-os;

II - atuação em todo o ciclo de vida e contexto de empreendimentos, inclusive na sua gestão e manutenção; e

III - atuação na formação e atualização de futuros engenheiros e profissionais envolvidos em projetos de produtos (bens e serviços) e empreendimentos. (BRASIL, 2019b, p. 3).

Esse quesito sobre os campos de atuação do(a) engenheiro(a) não era tratado nas diretrizes anteriores. Para Oliveira (2019a, p. 71), graças a esse artigo 5, "as novas DCNs realçam a atuação do(a) engenheiro(a) como inovador, empreendedor e também como professor". Isso deixa claro, mais uma vez, o encaminhamento dado pelas novas DCNs, ao exaltar esse perfil empreendedor em seus egressos, colocando-as diretamente conectadas aos interesses do mercado, inclusive no âmbito educacional, desde que os futuros engenheiros e profissionais estejam envolvidos em projetos de produtos (bens e serviços) e empreendimentos. Essa intenção das diretrizes ficará mais evidente ainda no próximo tópico, quando analisamos algumas pistas encontradas nos textos da Resolução CNE/CES n 2/2019 e do Parecer CNE/CES n ${ }^{\circ} 1 / 2019$.

\section{Pistas ao longo do caminho: para onde apontam as atuais DCNs de engenharia}

Analisando agora de uma maneira geral as atuais DCNs dos cursos de Engenharia, podemos encontrar, ao longo do texto da resolução que as institui, bem como do parecer que serviu de base para elas, algumas pistas que nos ajudam a reforçar a compreensão do caminho 
que elas seguem e para onde pretendem levar os(as) engenheiros(as). Essas pistas nada mais são do que a ocorrência de palavras e expressões que, neste ensaio, separamos em duas categorias específicas: Mercado e Sociedade, a fim de identificar qual destas duas se sobressai com o maior número de ocorrências e, com isso, visualizar de forma mais clara para onde apontam as atuais DCNs de Engenharia.

Na tabela 01, estão discriminadas algumas palavras e expressões extraídas do Parecer CNE/CES n ${ }^{\circ}$ 1.362/2001 (Brasil, 2002a) que serviu de base para a formulação das diretrizes anteriores dos cursos de Engenharia.

Tabela 1 - Registro de palavras por categoria - Parecer CNE/CES nº 1.362/2001

\begin{tabular}{|c|c|c|c|c|c|}
\hline \multicolumn{6}{|c|}{ CATEGORIA DE PALAVRAS } \\
\hline \multicolumn{2}{|l|}{ MERCADO } & \multirow{2}{*}{$\frac{32,4 \%}{\%}$} & \multicolumn{2}{|l|}{ SOCIEDADE } & \multirow{2}{*}{$\begin{array}{c}67,6 \% \\
\% \\
\end{array}$} \\
\hline Palavra/expressão & Ocor. & & Palavra/expressão & Ocor. & \\
\hline Econômico/economia & 3 & $25,0 \%$ & Meio ambiente/ambiental & 5 & $20,0 \%$ \\
\hline Produto/produção & 3 & $25,0 \%$ & Humanística/humano/humanidades & 3 & $12,0 \%$ \\
\hline Empresas & 1 & $8,3 \%$ & $\begin{array}{c}\text { Integração/atividades/aspecto } \\
\text { político(a) }\end{array}$ & 3 & $12,0 \%$ \\
\hline Liderança & 1 & $8,3 \%$ & Atividades/aspectos culturais & 2 & $8,0 \%$ \\
\hline Empreendedora & 1 & $8,3 \%$ & Integração/contexto social & 2 & $8,0 \%$ \\
\hline Flexível & 1 & $8,3 \%$ & Atividade/aspectos sociais & 2 & $8,0 \%$ \\
\hline Administração & 1 & $8,3 \%$ & Cidadão/cidadania & 1 & $4,0 \%$ \\
\hline Gestão econômica & 1 & $8,3 \%$ & Problemas em sua totalidade & 1 & $4,0 \%$ \\
\hline- & - & - & Múltiplas dimensões & 1 & $4,0 \%$ \\
\hline- & - & - & Base filosófica & 1 & $4,0 \%$ \\
\hline- & - & - & Formação sociocultural & 1 & $4,0 \%$ \\
\hline- & - & - & Atuação crítica & 1 & $4,0 \%$ \\
\hline- & - & - & Sociedade & 1 & $4,0 \%$ \\
\hline- & - & - & Ciências sociais & 1 & $4,0 \%$ \\
\hline Subtotal de registros & 12 & $100,0 \%$ & Subtotal de registros & 25 & $100,0 \%$ \\
\hline $\begin{array}{l}\text { Total de regist } \\
\text { mercado/socied }\end{array}$ & & & 37 & & \\
\hline
\end{tabular}

Fonte: Elaboração dos autores a partir do texto do Parecer CNE/CES nº 1.362/2001

Observando os dados apresentados na tabela 1, é possível verificar que a maioria dos registros coletados $(67,6 \%)$, ou seja, 25 de um total de 37, pertencem à categoria Sociedade, enquanto os 12 restantes $(32,4 \%)$ ficaram na categoria Mercado. Isso significa dizer que, considerando a ocorrência dos registros coletados, as questões sociais, representadas na categoria Sociedade, prevaleceram em relação às questões ligadas ao mercado, no parecer que embasou as diretrizes de 2002. 
Agora vejamos o registro apresentado na tabela 2, correspondente ao Parecer CNE/CES $\mathrm{n}^{\circ} 1 / 2019$ (BRASIL, 2019a).

Tabela 2 - Registro de palavras por categoria - Parecer CNE/CES nº 1/2019

\begin{tabular}{|c|c|c|c|c|c|}
\hline \multicolumn{6}{|c|}{ CATEGORIA DE PALAVRAS } \\
\hline \multicolumn{2}{|l|}{ MERCADO } & \multirow{2}{*}{$\begin{array}{c}71,1 \% \\
\% \\
\end{array}$} & \multicolumn{2}{|l|}{ SOCIEDADE } & \multirow{2}{*}{$\begin{array}{c}28,9 \% \\
\% \\
\end{array}$} \\
\hline Palavra/expressão & Ocor. & & Palavra/expressão & Ocor. & \\
\hline $\mathrm{MEI} / \mathrm{CNI}$ & 35 & $32,4 \%$ & Meio ambiente/ambiental & 6 & $13,6 \%$ \\
\hline Empresa/empresarial & 11 & $10,2 \%$ & Sociedade & 6 & $13,6 \%$ \\
\hline $\begin{array}{c}\text { Empreendedor(a)/empreendi- } \\
\text { mento } \\
\end{array}$ & 11 & $10,2 \%$ & $\begin{array}{c}\text { Direito/caráter/ } \\
\text { responsabilidade social }\end{array}$ & 5 & $11,4 \%$ \\
\hline Produtividade/produto & 10 & $9,3 \%$ & $\begin{array}{c}\text { Humanística/ser } \\
\text { humano/humanista }\end{array}$ & 3 & $6,8 \%$ \\
\hline $\begin{array}{l}\text { Mercado/mercadológico/mun-do } \\
\text { do trabalho }\end{array}$ & 6 & $5,6 \%$ & $\begin{array}{c}\text { Integração/inserção/diversida- } \\
\text { de social }\end{array}$ & 3 & $6,8 \%$ \\
\hline Indústria/industrial & 6 & $5,6 \%$ & $\begin{array}{c}\text { Integração/inserção/aspectos } \\
\text { políticos } \\
\end{array}$ & 3 & $6,8 \%$ \\
\hline Competitividade/competir & 3 & $2,8 \%$ & Cidadão/cidadania & 2 & $4,5 \%$ \\
\hline Recursos humanos & 3 & $2,8 \%$ & Comunidade (não acadêmica) & 2 & $4,5 \%$ \\
\hline Ranking & 3 & $2,8 \%$ & Atividades/aspectos culturais & 2 & $4,5 \%$ \\
\hline $\begin{array}{l}\text { Setor produtivo/mundo da } \\
\text { produção }\end{array}$ & 3 & $2,8 \%$ & $\begin{array}{c}\text { Assistência/desenvolvimento } \\
\text { social }\end{array}$ & 2 & $4,5 \%$ \\
\hline Flexibilidade & 3 & $2,8 \%$ & Aspectos sociais & 2 & $4,5 \%$ \\
\hline Mão de obra/manufatura & 2 & $1,9 \%$ & Direitos humanos & 1 & $2,3 \%$ \\
\hline IGI (Índice Global de Inovação) & 2 & $1,9 \%$ & Educação para a terceira-idade & 1 & $2,3 \%$ \\
\hline OCDE & 2 & $1,9 \%$ & Política de gênero & 1 & $2,3 \%$ \\
\hline Crescimento econômico & 2 & $1,9 \%$ & Relações étnico-raciais & 1 & $2,3 \%$ \\
\hline Capital humano & 1 & $0,9 \%$ & Desenvolvimento sustentável & 1 & $2,3 \%$ \\
\hline Mercado internacional & 1 & $0,9 \%$ & Crítico & 1 & $2,3 \%$ \\
\hline Recrutar & 1 & $0,9 \%$ & Reflexívo & 1 & $2,3 \%$ \\
\hline Liderança & 1 & $0,9 \%$ & Problemas em sua totalidade & 1 & $2,3 \%$ \\
\hline Gestão estratégica & 1 & $0,9 \%$ & - & - & - \\
\hline Empregabilidade & 1 & $0,9 \%$ & - & - & - \\
\hline Subtotal de registros & 108 & $100 \%$ & Subtotal de registros & 44 & $100 \%$ \\
\hline \multicolumn{2}{|c|}{ Total de registros mercado/sociedade } & \multicolumn{4}{|c|}{152} \\
\hline
\end{tabular}

Fonte: Elaboração dos autores a partir do texto do Parecer CNE/CES n ${ }^{\circ}$ 1/2019

A primeira coisa que chama a atenção é o total de registros (152). Isso se deve ao maior volume do documento que embasou as atuais diretrizes, se comparado com o parecer usado nas diretrizes anteriores. Por este motivo, obviamente, a quantidade de palavras e expressões 
seria superior às que foram apresentadas na tabela 1. Portanto, façamos uma comparação em termos percentuais.

$\mathrm{Na}$ tabela 2, podemos verificar que a categoria Mercado se sobressai com uma representação de $71,1 \%$ dos registros em relação ao total coletado, enquanto a outra categoria configura apenas $28,9 \%$ do total. É possível perceber também que, dentro da categoria Mercado, 32,4\% dos seus 108 registros correspondem às citações que fazem menção à Mobilização Empresarial pela Inovação (MEI/CNI), um movimento constituído por um grupo de grandes empresas brasileiras que é coordenado pela Confederação Nacional da Indústria (CNI). Sua participação nas discussões que levaram à formulação das novas DCNs está registrada no Parecer CNE/CES n ${ }^{\circ}$ 1/2019 através das referências feitas nele a todas as reuniões, audiências e demais encontros onde a MEI/CNI se fez presente. Isso demonstra o grande protagonismo que essa organização teve no processo de elaboração das atuais diretrizes dos cursos de Engenharia.

Nas tabelas 3 e 4 a seguir, fazemos a mesma análise, desta vez tomando como referência as Resoluções CNE/CES $n^{\circ} 11 / 2002$ (Brasil, 2002b) e $n^{\circ}$ 2/2019 (Brasil, 2019b), respectivamente.

Tabela 3 - Registro de palavras por categoria - Resolução CNE/CES nº 11/2002

\begin{tabular}{|c|c|c|c|c|c|}
\hline \multicolumn{6}{|c|}{ CATEGORIA DE PALAVRAS } \\
\hline \multicolumn{2}{|l|}{ MERCADO } & \multirow{2}{*}{$\begin{array}{c}32,0 \% \\
\%\end{array}$} & \multicolumn{2}{|l|}{ SOCIEDADE } & \multirow{2}{*}{$\begin{array}{c}68,0 \% \\
\%\end{array}$} \\
\hline Palavra/expressão & Ocor. & & Palavra/expressão & Ocor. & \\
\hline Aspectos/viabilidade/ econômicos & 2 & $25,0 \%$ & Meio ambiente/ambiental & 4 & $23,5 \%$ \\
\hline Produtos e processos & 1 & $12,5 \%$ & $\begin{array}{l}\text { Aspectos/contexto/ciências } \\
\text { sociais }\end{array}$ & 3 & $17,6 \%$ \\
\hline Empresas & 1 & $12,5 \%$ & Formação/ atuação crítica & 2 & $11,8 \%$ \\
\hline Atividades empreendedoras & 1 & $12,5 \%$ & Formação humanista & 1 & $5,9 \%$ \\
\hline Administração & 1 & $12,5 \%$ & Formação reflexiva & 1 & $5,9 \%$ \\
\hline Economia & 1 & $12,5 \%$ & Aspectos políticos & 1 & $5,9 \%$ \\
\hline Gestão econômica & 1 & $12,5 \%$ & Aspectos culturais & 1 & $5,9 \%$ \\
\hline- & - & - & Visão humanística & 1 & $5,9 \%$ \\
\hline- & - & - & Sociedade & 1 & $5,9 \%$ \\
\hline- & - & - & Humanidades & 1 & $5,9 \%$ \\
\hline- & - & - & Cidadania & 1 & $5,9 \%$ \\
\hline Subtotal de registros & 8 & $100,0 \%$ & Subtotal de registros & 17 & $100,0 \%$ \\
\hline \multicolumn{2}{|c|}{ Total de registros mercado/sociedade } & \multicolumn{4}{|c|}{25} \\
\hline
\end{tabular}

Fonte: Elaboração dos autores a partir do texto da Resolução CNE/CES n 11/2002 
Tabela 4 - Registro de palavras por categoria - Resolução CNE/CES n²/2019

\begin{tabular}{|c|c|c|c|c|c|}
\hline \multicolumn{6}{|c|}{ CATEGORIA DE PALAVRAS } \\
\hline \multicolumn{2}{|l|}{ MERCADO } & $\mathbf{5 7 , 7 \%}$ & \multicolumn{2}{|l|}{ SOCIEDADE } & $42,3 \%$ \\
\hline Palavra/expressão & Ocor. & $\%$ & Palavra/expressão & Ocor. & $\%$ \\
\hline $\begin{array}{c}\text { Aspectos/viabilidade/contexto } \\
\text { econômicos }\end{array}$ & 5 & $16,7 \%$ & Meio ambiente/ambiental & 6 & $27,3 \%$ \\
\hline Produtos e processos & 4 & $13,3 \%$ & $\begin{array}{c}\text { Aspectos/responsabilidade/ } \\
\text { contextos sociais }\end{array}$ & 6 & $27,3 \%$ \\
\hline $\begin{array}{l}\text { Empreendedor(a)/ } \\
\text { empreendimentos }\end{array}$ & 4 & $13,3 \%$ & Aspectos/contextos culturais & 2 & $9,1 \%$ \\
\hline Liderar & 3 & $10,0 \%$ & Visão crítica & 1 & $4,5 \%$ \\
\hline Empresas & 3 & $10,0 \%$ & Visão reflexiva & 1 & $4,5 \%$ \\
\hline Incubadoras & 1 & $3,3 \%$ & Aspectos políticos & 1 & $4,5 \%$ \\
\hline Administração & 1 & $3,3 \%$ & Visão humanista & 1 & $4,5 \%$ \\
\hline Economia & 1 & $3,3 \%$ & Sociedade & 1 & $4,5 \%$ \\
\hline Estruturas empreendedoras & 1 & $3,3 \%$ & Diferenças socioculturais & 1 & $4,5 \%$ \\
\hline Produção de finanças & 1 & $3,3 \%$ & Desenvolvimento sustentável & 1 & $4,5 \%$ \\
\hline Mercado & 1 & $3,3 \%$ & Demandas humanas & 1 & $4,5 \%$ \\
\hline Gestão de empreendimentos & 1 & $3,3 \%$ & - & - & - \\
\hline $\begin{array}{l}\text { Manutenção de } \\
\text { empreendimentos }\end{array}$ & 1 & $3,3 \%$ & - & - & - \\
\hline Organizações privadas & 1 & $3,3 \%$ & - & - & - \\
\hline Competições & 1 & $3,3 \%$ & - & - & - \\
\hline Governança & 1 & $3,3 \%$ & - & - & - \\
\hline Subtotal de registros & 30 & $100,0 \%$ & Subtotal de registros & 22 & $100,0 \%$ \\
\hline \multicolumn{2}{|c|}{ Total de registros mercado/sociedade } & \multicolumn{4}{|c|}{52} \\
\hline
\end{tabular}

Fonte: Elaboração dos autores a partir do texto da Resolução CNE/CES nº2/2019

Analisando essas duas últimas tabelas (3 e 4) que fazem referência às resoluções que instituíram as diretrizes curriculares de 2002 e 2019, podemos perceber a mesma inversão de direcionamento de uma diretriz para a outra, observada anteriormente na comparação entre os dois pareceres. No texto de 2002 das diretrizes, representado aqui pela tabela 3, 68\% dos registros encontrados faziam referência à categoria Sociedade. Já em relação ao texto das diretrizes de 2019, a categoria Mercado foi quem obteve maioria nos registros, atingindo $57,7 \%$ do total de palavras e expressões coletadas.

Em relação ao número de registros observados nas duas resoluções, para cada categoria, identificamos um leve aumento de palavras/expressões ligadas à categoria Sociedade (5 a mais) nas atuais diretrizes, no entanto, se compararmos este aumento aos valores obtidos na categoria Mercado, vemos que ele se torna praticamente irrisório frente aos 22 registros a mais de palavras/expressões ligadas ao Mercado na Resolução de 2019. 
Esperava-se obter uma quantidade total de registros maior na Resolução CNE/CES $n^{\circ} 2 / 2019$, visto que esta possui um texto mais denso em relação à anterior. O texto de 2019 possui 6 páginas contendo 18 artigos, divididos em seis capítulos, enquanto o de 2002 é mais enxuto, apresentando apenas 9 artigos distribuídos em 4 páginas. Portanto, justifica-se o aumento no número total de palavras/expressões coletadas.

Quanto à mudança de direcionamento, que antes tendia para a categoria Sociedade e atualmente se inclina para o Mercado, a única justificativa que encontramos está relacionada aos interesses da classe empresarial, representada no decorrer do processo de elaboração desses documentos pela MEI/CNI, em assumir o domínio sobre a educação e, portanto, direcioná-la para seus interesses próprios.

\section{A mobilização empresarial pela inovação - MEI/CNI}

Conforme foi visto até aqui, a Mobilização Empresarial pela Inovação (MEI/CNI), teve um grande protagonismo na estruturação das atuais Diretrizes Curriculares Nacionais do curso de graduação em Engenharia (Resolução CNE/CES n 2, de 24 de abril de 2019). Criado em 2008, este movimento que reúne lideranças de grandes empresas da indústria no Brasil e é coordenado pela Confederação Nacional da Indústria (CNI) traz como slogan o discurso de que "as indústrias brasileiras precisam de políticas públicas que atendam exatamente suas necessidades"15 . É nessa direção que elas seguem, segundo site do Portal da Indústria, "como protagonista na colaboração e no engajamento entre os setores privado, público e acadêmico, aponta para a importância da proposição de políticas públicas de CT\&I, que visem ampliar e orientar capacidades, ativos, vocações e competências" ${ }^{16}$.

Kern, Sagazio, et al. (2019, p. 34) afirmam que "a MEI tem defendido a necessidade de (re)adequação dos currículos às demandas do mercado, que exige crescentemente dos profissionais habilidades como soft skills ${ }^{17}$, ainda hoje subvalorizadas em muitas escolas". Observamos muito claramente essa atuação da MEI e seu protagonismo, a partir das referências a esse movimento no texto do Parecer CNE/CES $n^{\circ} 1 / 2019$, que, conforme visto na tabela 1 do tópico anterior, teve 35 ocorrências, significando 32,4\%, do total de ocorrências da categoria Mercado.

Nesse parecer são acrescentadas diversas matérias, veiculadas na mídia, reportando a atuação das empresas na formulação dos cursos de Engenharia no Brasil, como a que saiu na Folha de São Paulo, em 5 de dezembro de 2018, descrevendo a necessidade, do ponto de vista da indústria, que esses cursos têm de "passar por mudanças no currículo para formar profissionais capazes de lidar com os desafios trazidos pela indústria 4.0 - conceito que engloba a adoção de tecnologias digitais nos processos fabris"18.

Em seu texto, intitulado "A mobilização empresarial pela inovação (MEI) e a defesa da modernização do ensino de Engenharia”, publicado no ano de aprovação das atuais DCNs de Engenharia, Kern, Sagazio, et al. (2019, p. 35) fazem referência ao manifesto "Inovação: A Construção do Futuro", escrito em 2009 pela MEI/CNI, em que ela chama a atenção para a necessidade de se "aprimorar nosso modelo educacional, para criar uma cultura inovadora e 
empreendedora.” (MEI/CNI, 2009, p.11, apud KERN, SAGAZIO, et al., 2019, p. 35). Para estes autores todas essas mudanças na educação superior são importantes, pois proporcionam

[...] condições para que os jovens saiam dos cursos mais bem preparados para empreender por conta própria, para empreender no interior das empresas, para competir com as máquinas cada vez mais inteligentes que conquistam os mercados. (Kern, Sagazio, et al., 2019, p. 40).

Eis então a justificativa, apresentada pelas indústrias, para direcionar as novas Diretrizes Curriculares Nacionais dos cursos de Engenharia aos seus interesses, ampliando, assim, esse enfoque mercadológico no texto das diretrizes e, consequentemente, na formação do(a) engenheiro(a).

\section{A visão humanística na engenharia}

Este perfil humanístico é um dos pontos mais curiosos na atual Resolução, pois, ao ser colocado como o primeiro na lista das habilidades a serem alcançadas pelos egressos dos cursos de Engenharia, inicialmente, tem-se a impressão de que o atual currículo realmente trará para o(a) engenheiro(a) esta característica - pensar os problemas em sua totalidade e ser crítico e reflexivo ao buscar a solução dos mesmos dentro da sociedade. No entanto, percebe-se que este perfil não chega a ser sequer contemplado dentro da lista de conteúdos básicos propostos pelas atuais DCNs de Engenharia, conforme mencionado no item 3.3 acima.

A retirada desses componentes tem sido comumente justificada pela falta de interesse dos alunos de Engenharia em cursar disciplinas ligadas a estas áreas. De acordo com Raymann, Campos e Resende (2017), em pesquisa realizada com alunos, quando questionados sobre o motivo para cursar disciplinas relacionadas às Ciências Humanas, $83,3 \%$ dos alunos responderam que estavam apenas interessados no cumprimento da carga horária obrigatória, enquanto apenas $12,7 \%$ estavam realmente interessados no conteúdo da disciplina. Silveira e Bazzo (2007, p.10) afirmam que "as disciplinas que têm como proposta exercitar a reflexão crítica [...] são deixadas de lado e consideradas como 'perfumaria' [...], 'perda de tempo' pelos alunos e por muitos professores".

Essa justificativa se mostra bastante superficial e não remete a uma questão crucial: a falta de percepção desses(as) engenheiros(as) da instrumentalidade a que estão submetidos em um curso que visa apenas à formação técnica.

Por isso, apesar dos registros citados, consideramos que simplesmente cortar esses componentes das diretrizes ao invés de reforçar sua integração com os demais não se configura como a solução mais acertada para resolver o problema. Desta forma, esta característica humanística do perfil ficará, de acordo com a Resolução CNE/CES 02/2019 (BRASIL, 2019b), a cargo de atividades complementares de extensão e da atuação do corpo docente, a depender, é claro, do próprio perfil do professor. 
Mas por que manter no texto esse perfil humanístico? É provável que isso tenha ocorrido unicamente para atender ao que determina a LDB/1996 em seu artigo $43^{\circ}$ que trata da educação superior, ao afirmar que esta tem por finalidades

I - estimular a criação cultural e o desenvolvimento do espírito científico e do pensamento reflexivo;

II - formar diplomados nas diferentes áreas de conhecimento, aptos para a inserção em setores profissionais e para a participação no desenvolvimento da sociedade brasileira, e colaborar na sua formação contínua;

III - incentivar o trabalho de pesquisa e investigação científica, visando o desenvolvimento da ciência e da tecnologia e da criação e difusão da cultura, e, desse modo, desenvolver o entendimento do homem e do meio em que vive;

IV - promover a divulgação de conhecimentos culturais, científicos e técnicos que constituem patrimônio da humanidade e comunicar o saber através do ensino, de publicações ou de outras formas de comunicação;

$\mathrm{V}$ - suscitar o desejo permanente de aperfeiçoamento cultural e profissional e possibilitar a correspondente concretização, integrando os conhecimentos que vão sendo adquiridos numa estrutura intelectual sistematizadora do conhecimento de cada geração;

VI - estimular o conhecimento dos problemas do mundo presente, em particular os nacionais e regionais, prestar serviços especializados à comunidade e estabelecer com esta uma relação de reciprocidade;

VII - promover a extensão, aberta à participação da população, visando à difusão das conquistas e benefícios resultantes da criação cultural e da pesquisa científica e tecnológica geradas na instituição;

VIII - atuar em favor da universalização e do aprimoramento da educação básica, mediante a formação e a capacitação de profissionais, a realização de pesquisas pedagógicas e o desenvolvimento de atividades de extensão que aproximem os dois níveis escolares. (BRASIL, 1996, n.p., grifo nosso).

Esse não é um questionamento recente na formação do(a) engenheiro(a). Menestrina e Bazzo (2008, p.5) já lembravam que este distanciamento das humanidades nos cursos "conduziu a uma concepção de universidade com enfoque utilitarista, direcionada apenas às necessidades do mercado, a serviço do desenvolvimento econômico e tecnológico com vistas a um modelo empresarial". Essa afirmação fica evidente nas tabelas aqui apresentadas com o registro de termos ligados ao mercado e à sociedade, onde vemos que esta perdeu visivelmente espaço para o mercado nas atuais diretrizes graças ao grande esforço da Mobilização Empresarial pela Inovação.

No que diz respeito a uma formação mais cidadã do(a) engenheiro(a), Menestrina e Bazzo (2008) afirmam ainda que esta

[...] refere-se à inclusão dos acadêmicos nas problemáticas das comunidades e o estabelecimento por ele e por todos os envolvidos no processo de aprendizagem de pontes entre os conteúdos ministrados na sua graduação e as relações que pode 
constituir entre a sua profissionalização e a sociedade. Isso minimiza as críticas de que muitos estudantes passam pela universidade sem terem contato prático com a realidade e não conseguem produzir conhecimentos capazes de sanar os problemas sociais mais emergentes. (MENESTRINA; BAZZO, 2008, p. 4).

Um pequeno exemplo de como esse perfil humanístico pode ser desconsiderado pelas IES está no PPC do recém-criado curso de Engenharia civil do Instituto Federal de Educação Ciência e Tecnologia do Rio Grande do Norte (IFRN) ${ }^{19}$, que já foi elaborado com base nas atuais DCNs. Nele pode-se observar que, além de não reservar componentes curriculares específicos da área de humanidades que garantam a integração deste perfil às disciplinas técnicas, estas próprias disciplinas não apresentam em suas ementas praticamente nenhuma referência ao perfil humanístico. As exceções estão em "Ciências do Ambiente" — disciplina isolada no $4^{\circ}$ período do curso - e "Introdução à Engenharia Civil", disciplina do $1^{\circ}$ período que, mesmo apresentando ementa diretamente ligada a um perfil de caráter crítico e reflexivo, deixa a desejar na bibliografia indicada, levando a crer que ela se tornará uma mera disciplina isolada de início de curso com o intuito apenas de apresentar a história da engenharia, suas funções, áreas de atuação do(a) engenheiro(a) civil e a regulamentação da profissão. Por mais que haja alguma integração, isoladas em seus períodos específicos estas duas disciplinas, provavelmente, não terão impacto algum sobre o perfil almejado para os egressos.

Neste sentido, consideramos importante propor para os cursos, além da possibilidade de ofertar disciplinas complementares de caráter crítico/reflexivo ao longo de todos os períodos, reforçar também a participação em projetos de extensão de cunho cultural/social que favoreçam o contato dos alunos com a sociedade, além de solidificar projetos integradores e a participação em pesquisas que beneficiem não só o mercado, mas também a sociedade.

\section{Considerações Finais}

Chegamos ao fim deste ensaio talvez trazendo mais questionamentos e reflexões do que respostas. $\mathrm{Na}$ verdade, como pudemos ver, sempre esteve muito claro para onde as DCNs dos cursos de Engenharia apontam, visto que o setor industrial e o mercado de maneira geral, sempre deixaram isso muito explícito em todas as publicações feitas na área no decorrer do processo de construção das atuais diretrizes. A pergunta que fizemos no título — de forma retórica - e respondemos de forma categórica, buscou, de certa maneira, trazer mais uma reflexão sobre para onde as diretrizes curriculares não apontam e por que não apontam, além, é claro, de chamar a atenção para a função social do(a) engenheiro(a) e a pressão que sua formação sofre graças ao poder exercido pela cultura hegemônica sobre os currículos.

Em relação aos currículos de Engenharia, tem-se falado muito que um dos motivos do alto índice de evasão nos cursos está ligado, em parte, ao desinteresse dos alunos, devido à ausência de inovação tecnológica nos projetos pedagógicos dos cursos. Este foi inclusive um dos motivos que levaram à atualização das DCNs de Engenharia. No entanto, acreditamos que um dos maiores problemas que influem para o alto índice de evasão, esteja mais 
relacionado com a forma como determinados componentes curriculares são ministrados e, acima de tudo, com a falta de conhecimento sobre os motivos para cursá-los.

Saber para que cursá-los e onde aplicar os conhecimentos adquiridos em prol da sociedade, poderia influir significativamente no aumento do interesse dos alunos em permanecer no curso. A ausência de um propósito válido, que tenta ser suprida pela presença de meros sonhos líquidos que se esvaem por entre os dedos, ao se depararem com grandes momentos de crise como essa em que estamos vivendo, isto sim, pode contribuir fortemente para o abandono dos cursos. A análise apresentada neste texto mostra que a formação dos(a) engenheiro(as), tal como proposta nos documentos estudados, não os forma nem para o enfrentamento pessoal nem para o enfrentamento social de situações como as que vivenciamos hoje com o novo coronavírus (SARS-CoV-2). Isto se deve ao fato de que seu foco é a competitividade individual, a produção e a gestão de processos de engenharia. Em decorrência disso há uma negligência dos aspectos sociais da profissão e sua formação humana como sujeito histórico, cultural e social, que vive em comunidade e que, portanto, tem responsabilidade pela construção de uma sociedade igualitária.

Desta forma, saber para que servem as instituições de ensino e o que está em jogo quando pensamos a educação dentro de um contexto de crise, são questões que, esperamos, podem ser envolvidas pelas reflexões geradas no presente ensaio. Reflexões que não estão necessariamente ligadas à educação do(a) engenheiro(a), mas a toda e qualquer formação.

Por fim, é importante frisarmos que não se pretende aqui desconsiderar a formação técnica para o mercado de trabalho na formação do engenheiro(a) nem os problemas econômicos e todos os prejuízos gerados como consequência tanto para o mercado quanto para a sociedade, mas sim advogar por uma maior equiparidade entre o foco no mercado e o foco na sociedade, na ação social, não apontando um ou outro como principal ou ponto de chegada, mas mantendo-os lado a lado, margeando os caminhos a serem traçados com base nas diretrizes planejadas, a fim de se obter, efetivamente, uma formação integral do indivíduo.

\section{Notas}

1. Reforma trabalhista. Disponível em: http://www.planalto.gov.br/ccivil_03/_ato20152018/2017/lei/113467.htm. Acesso em: 10/08/2020

2. Reforma do Ensino Médio. Disponível em: http://www.planalto.gov.br/ccivil_03/_ato20152018/2017/lei/113415.htm. Acesso em: 10/08/2020

3. Emenda Constitucional $\mathrm{n}^{\mathrm{o}} \quad 95 . \quad$ Disponível em: https://legis.senado.leg.br/norma/540698/publicacao/15655553. Acesso em: 10/08/2020.

4. Programa Escola Sem Partido. Disponível em: https://www.camara.leg.br/proposicoesWeb/fichadetramitacao?idProposicao=2190752. Acesso em $12 \mathrm{de}$ agosto de 2020.

5. Lei $n^{\circ}$ 9.131/1995. Disponível em: http://www.planalto.gov.br/ccivil_03/leis/19131.htm. Acesso em: 15 de agosto de 2020 . 
6. Parecer $\mathrm{n}^{\mathrm{o}}$ 776/1997. Disponível em: http://portal.mec.gov.br/setec/arquivos/pdf_legislacao/superior/ legisla_superior_parecer77697.pdf. Acesso em: 23 de agosto de 2020.

7. Edital MEC nº 04, de 10 de dezembro de 1997. Disponível em: http://portal.mec.gov.br/sesu/arquivos/pdf/ e04.pdf. Acesso em: 23 de agosto de 2020

8. Resolução $n^{\circ}$ 1, de 2 de fevereiro de 2006. Disponível em: http://portal.mec.gov.br/cne/arquivos/ pdf/rces01_06.pdf. Acesso em: 15 de agosto de 2020.

9. Resolução $\mathrm{n}^{\mathrm{o}}$ 2, de 2 de fevereiro de 2006. Disponível em: http://portal.mec.gov.br/cne/arquivos/pdf/ rces02_06.pdf. Acesso em: 15 de agosto de 2020.

10. Resolução $\mathrm{n}^{\circ}$ 5, de 2 de fevereiro de 2006. Disponível em: http://portal.mec.gov.br/cne/arquivos/pdf/ rces05_06.pdf. Acesso em: 15 de agosto de 2020.

11. Resolução $\mathrm{n}^{\circ} 1$, de 6 de janeiro de 2015. Disponível em: http://portal.mec.gov.br/index.php?option=com docman\&view=download\&alias=16871-res-cne-ces-001-06012015\&Itemid=30192. Acesso em: 15 de agosto de 2020.

12. A nova resolução traz o texto no singular.

13. Instituto Brasileiro de Coaching - IBC. Disponível em: https://www.ibccoaching.com.br/portal/conheca-asprincipais-caracteristicas-de-uma-visao-holistica-na-administracao/. Acesso em: 19 de agosto de 2020.

14. Dicionário online de português. Disponível em: https://www.dicio.com.br/generalista/. Acesso em: 19 de agosto de 2020.

15. Portal da Indústria. Disponível em: http://www.portaldaindustria.com.br/cni/canais/mei/. Acesso em: 20 de agosto de 2020 .

16. Portal da Indústria. Disponível em: http://www.portaldaindustria.com.br/cni/canais/mei/o-que-e-a-mei/. Acesso em: 20 de agosto de 2020.

17. Habilidades interpessoais.

18. Folha de São Paulo. Indústria 4.0 pede engenheiro empreendedor e comunicativo. 2018. Disponível em: https:/www1.folha.uol.com.br/seminariosfolha/2018/12/industria-40-pede-engenheiro-empreendedor-ecomunicativo.shtml. Acesso em: 20 de agosto de 2020.

19. Projeto Pedagógico do Curso de Engenharia Civil - IFRN. Disponível em: https://portal.ifrn.edu.br/ensino/ cursos/cursos-de-graduacao/engenharias/engenharia-civil/view. Acesso em: 18 de agosto de 2020.

\section{Referências}

BRASIL. Lei No 9.394 - Lei de Diretrizes e Bases da educação nacional. Diário Oficial da União, Brasília, 20 Dezembro 1996. Disponível em: <http://www.planalto.gov.br/ccivil_03/leis/19394.htm>. Acesso em: 15 agosto 2020.

BRASIL. Conselho Nacional de Educação. Parecer CNE/CES, de 12 de dezembro de 2001. Diretrizes Curriculares Nacionais dos Cursos de Engenharia. Diário Oficial da União, Brasília, 25 fevereiro 2002 a. Disponível em: <http://portal.mec.gov.br/cne/arquivos/pdf/CES1362.pdf>. Acesso em: 15 agosto 2020.

BRASIL. Conselho Nacional de Educação. Resolução CNE/CES no 11, de 11 de março de 2002. Institui Diretrizes Curriculares Nacionais dos cursos de Engenharia. Diário Oficial da União, Brasília, 09 abril 2002b. Disponível em: <http://portal.mec.gov.br/index.php?option=com_docman\&view= download\&alias=15766-rces011-02\&category_slug=junho-2014-pdf\&Itemid=30192>． Acesso em: 15 agosto 2020 . 
BRASIL. Lei n ${ }^{\circ}$ 13.005/2014 - Aprova o Plano Nacional de Educação - PNE e dá outras providências. Diário Oficial da União, Brasília, 25 junho 2014. Disponível em: <http://www.planalto.gov.br/ccivil_03/_ ato2011-2014/2014/lei/113005.htm>. Acesso em: 15 agosto 2020.

BRASIL. Emenda Constitucional $\mathrm{n}^{\circ}$ 95, de 15 de dezembro de 2016, 15 dezembro 2016. Disponível em: <https://legis.senado.leg.br/norma/540698/publicacao/15655553>. Acesso em: 10 agosto 2020.

BRASIL. Lei $\mathrm{n}^{\circ}$ 13.415, de 16 de fevereiro de 2017, 17 fevereiro 2017a. Disponível em: <http://www.planalto.gov.br/ccivil_03/_ato2015-2018/2017/lei/113415.htm>. Acesso em: 10 agosto 2020.

BRASIL. Lei $\mathrm{n}^{\circ}$ 13.467, de 13 de julho de 2017, 14 julho 2017b. Disponível em: <http://www.planalto.gov.br/ccivil_03/_ato2015-2018/2017/lei/113467.htm>. Acesso em: 10 agosto 2020.

BRASIL. Conselho Nacional de Educação. Parecer CNE/CES nº 1 , de 23 de janeiro de 2019. Diretrizes Curriculares Nacionais do Curso de Graduação em Engenharia. Diário Oficial da União, Brasília, 23 abril 2019a. Disponível em: <http://portal.mec.gov.br/docman/janeiro-2019-pdf/106581-pces001-19/file〉. Acesso em: 15 agosto 2020.

BRASIL. Conselho Nacional de Educação. Resolução CNE/CES no 2, de 24 de abril de 2019. Institui as Diretrizes Curriculares Nacionais do curso de Engenharia. Diário Oficial da União, Brasília, p. 43-44, 26 abril 2019b. Disponível em: <http://portal.mec.gov.br/index.php?option=com_docman\&view= download\&alias=112681-rces002-19\&category_slug=abril-2019-pdf\&Itemid=30192>. Acesso em: 15 agosto 2020.

KERN, M.; SAGAZIO, G.; LOURENÇÃO, P.; PEREIRA, S.; MIRANDA, Z.; LOPES, A. A Mobilização Empresarial pela Inovação (MEI) e a defesa da modernização do ensino de Engenharia. In: OLIVEIRA, V. F. D. A engenharia e as novas DCNs: oportunidades para formar mais e melhores engenheiros. $1^{\text {a }}$. ed. Rio de Janeiro: LTC, 2019. p. 33-42.

KLIEBARD, H. M. Burocracia e teoria de currículo. Currículo sem fronteiras, v. XI, n. 2, p. 5-22, dezembro 2011. ISSN 1645-1384. Disponível em: http://www.curriculosemfronteiras.org/vol11iss2articles/kliebardburocracia.htm. Acesso em: 15 agosto 2020.

MENESTRINA, T. C.; BAZZO, W. A. Ciência, tecnologia e sociedade e formação do engenheiro: análise da legislação vigente. Revista Brasileira de Ensino de Ciência e Tecnologia - RBECT, v. 1, n. 2, p. 1-18, 2008. ISSN 1982-873X. Disponível em: https://periodicos.utfpr.edu.br/rbect/article/view/228. Acesso em: 15 agosto 2020.

MOURA, D. H. Reforma do ensino médio e o impacto na formação de professores. Semana de Física 2020 online, Petrolina, 10 julho 2020. Disponível em: <https://youtu.be/Y6JjMMTZE34〉. Acesso em: 10 julho 2020. Informação verbal.

NOSELLA, P. O princípio educativo do trabalho na formação humana: una spaccatura storica [uma histórica divisão] (Pasolini,2002, 1963). VIII Seminário Internacional de Teoria Política - Gramsci. Marília: UNESP. 2019. p. 23.

OLIVEIRA, V. F. D. As inovações nas atuais diretrizes para a Engenharia: estudo comparativo com as anteriores. In: OLIVEIRA, V. F. D. A Engenharia e as novas DCNs: Oportunidade para formar mais e melhores engenheiros. $1^{\mathrm{a}}$. ed. Rio de Janeiro: LTC, 2019a. p. 66-85.

OLIVEIRA, V. F. D. Evolução da organização do curso de Engenharia no Brasil. In: OLIVEIRA, V. F. D. A Engenharia e as novas DCNs: Oportunidades para formar mais e melhores engenheiros. $1^{\text {a }}$. ed. Rio de Janeiro: LTC, 2019b. p. 8-32.

PRADO, L. A. D.; ALENCASTRO, M. S. C.; ALMEIDA, S. D. C. D. D. Currículo: Instrumento de poder e de transformação cultural. Anais do XIII Congresso Nacional de Educação. Curitiba: Educere. 2017. p. 17496-17508. Disponível em: https://educere.bruc.com.br/arquivo/pdf2017/23790_12178.pdf. Acesso em: 30 outubro 2020. 
RAYMANN, M. S.; CAMPOS, D. B. D.; RESENDE, L. M. M. D. Investigação sobre a importância que alunos de Engenharia atribuem às disciplinas de ciências humanas. Anais do XLV Congresso Brasileiro de Educação em Engenharia, Joinville, setembro 2017. Disponível em: http://www.abenge.org.br/sis_artigos.php. Acesso em: 30 outubro 2020.

SILVA, T. T. D. Documentos de identidade: uma introdução às teorias do currículo. $3^{\mathrm{a}}$. ed. Belo Horizonte: Autêntica, 2010.

SILVEIRA, R. M. C. F.; BAZZO, W. A. Educação tecnológica: qual o seu papel? Anais do XXXV Congresso Brasileiro de Educação em Engenharia, Curitiba, setembro 2007. 1-15. Disponível em: http://www.abenge.org.br/cobenge/interna.php?ss=12\&ctd=78. Acesso em: 30 outubro 2020.

\section{Correspondência}

Kleiton Cassemiro: É Graduado em Engenharia Civil, atualmente atua como Professor do IFRN na área de Construção Civil e é Doutorando do Programa de Pós-Graduação em Educação Profissional do IFRN PPGEP/IFRN, na Linha de Formação Docente e Práticas Pedagógicas em Educação Profissional.

E-mail: kleiton.cassemiro@ifrn.edu.br

Ana Lúcia Sarmento Henrique: É Graduada em Letras e com Doutorado em Educação. Atualmente atua como Professora do IFRN, lecionando no Programa de Pós-Graduação em Educação Profissional PPGEP/IFRN. Também atua como coordenadora do GT 18 da ANPED (Educação de Jovens e Adultos).

E-mail: ana.henrique@ifrn.edu.br

Texto publicado em Currículo sem Fronteiras com autorização dos autores 